\title{
THE LIMITS OF LITIGATION: PUBLIC HOUSING SITE SELECTION AND THE FAILURE OF INJUNCTIVE RELIEF
}

Mr. Justice Holmes once wrote that "[h]ousing is a necessary of life," yet for millions of Americans, satisfactory housing has never been anything more than an unfulfilled promise. ${ }^{2}$ In partial response to this national failure, and to the exacerbation of that failure since the 1930's, Congress has attempted to provide legislative relief through several subsidization programs. ${ }^{3}$ The Depression produced the first of these responses, the Housing Act of 1937. ${ }^{4}$ While motives other than improving the housing opportunities of poor families may have played a major role in the Congressional decision to enact the bill, ${ }^{5}$ the effect was nonetheless to create a joint federal-local administrative and financial scheme that has survived to the present day as the nation's primary response to the problem of low-income housing. ${ }^{6}$ Because the Act led to the construction of aesthetically neutral

1 Block v. Hirsh, 256 U.S. 135, I56 (1921) (dictum).

2 In 1950, there were $15,256,000$ occupied dwelling units in substandard condition; in 1960, there were $9,007,000$. Of all nonwhite families living in urban areas and earning less than $\$ 2,000$ annually in $1960,45 \%$ resided in substandard housing. Twenty-eight percent of all urban blacks, regardless of income, resided in substandard housing. The President's Comm. on Urban Housing, A Decent Home 44 (1968).

${ }^{3}$ See, e.g., 12 U.S.C. $\$ \S 1701 \mathrm{q}, 1701 \mathrm{~s}, 1709,1713,1715 \mathrm{e}, 1715 \mathrm{l}, 1715 \mathrm{~m}, 1715 \mathrm{v}$, $1715 y, 1715 z, 1715 z-1$ (1970); 42 U.S.C. \& $1421 b(1970)$. These programs contemplate either direct subsidization of indigent housing consumers or insurance or mortgage financing made available by the private sector. See also National Comm'N ON URBAN Problems, Building the American Gity 143-51 (1968).

442 U.S.C. $\$ \S 1401-30$ (1970).

5It has been suggested that federally subsidized housing construction was designed to create jobs and to fight the ravages of Depression unemployment. L. FRIEDman, Government and Stum Housing 106 (1968); Friedman, Public Housing and the Poor: An Overview, 54 Calif. L. Rev. 642, 645-47 (1966) [hereinafter cited as Public Housing]. This theory is well supported by the language of the statute. Its initial section, the declaration of policy, states that "[i]t is declared to be the policy of the United States to promote the general welfare of the Nation by employing its funds and credit, . . . to alleviate present and recurring unemployment . . ." 42 U.S.C. $\$ 1401$ (1970). Section 12 provides for federal administration of certain housing projects "in order to continue the relief of Nationwide unemployment . . ." 42 U.S.C. \$ 1412(a) (1970).

${ }^{6}$ Through 1967, a total of 632,923 public housing units had been completed. National Comm'n on Urban Problems, supra note 3, at 130 (1968). State financed public housing programs do exist, but their impact has been marginal in comparison to the federal program. See, e.g., ConN. Gen. STAT. ANN. §§ 8-69 to 94, 8-114a (1971); Mass. Gen. Laws Ann. ch. 121B, $\S \S 34-37,41$ (Supp. 1973); N.Y. Pub. Hous. Law (McKinney 1955), as amended, (Supp. 1973), especially $\$ \$ 70-76$. 
housing occupied by families that were only temporarily impoverished as a result of the Depression, ${ }^{7}$ the public housing program initially met with a degree of acceptance and success. ${ }^{8}$ Over the years, however, support has dwindled. As the political power of public housing tenants fell, the social and political palatability of public housing declined correspondingly. ${ }^{9}$ Efforts by white residents to delay or to stop construction of housing projects that threatened their neighborhoods have become fairly common. ${ }^{10}$ Due in part to this opposition, many local public housing authorities have begun to build their projects either exclusively or primarily in their cities' slums, ${ }^{11}$ where most residents are black and almost all are poor.

During the late 1960's, however, an interesting pattern emerged. Opposition to construction of public housing in ghettos began to emanate from the putative beneficiaries of that

${ }^{7}$ Public Housing, supra note 5 , at $645-47$.

8 This was true despite strong opposition by the private interests arrayed against the program-realtors, home builders, and savings and loan associations-that had vested interests in keeping all housing construction in the private sector. Further popular opposition to the program sprang from the capitalist ethos: not only was it to be for the benefit of the poor, it also ran counter to the ingrained concept of homeownership. L. Freedman, Public Housing: The Politics of Poverty 6-10 (1969).

"Public Housing, supra note 5, at 651-52.

${ }^{10} \mathrm{Cf}$. Special Project, Public Housing, 22 Vand. L. Rev. 875, 900 (1969). The situation which resulted in the much publicized recent litigation in New York is a good example of an attempt by whites to prevent the construction of public housing in their neighborhoods. Forest Hills Residents Ass'n v. New York City Housing Authority, 69 Misc. 2d 42, 329 N.Y.S.2d 69 (Sup. Ct.), rev'd per curiam, 39 App. Div. 2d 64, 332 N.Y.S.2d 156, aff'd sub nom. Margulis v. Lindsay, 31 N.Y.2d 167, 286 N.E.2d 724, 335 N.Y.S.2d 285 (1972). See Goodman, The Battle of Forest Hills-Who's Ahead? N.Y. Times, Feb. 20, 1972, § 6 (Magazine), at 8. See also National Comm'n ON URBAN Problems, supra note 3, at 129-30, suggesting that opposition is due primarily to four factors: dislike of public intervention in housing; fear of large government expenditures; the wish to be physically distant from poor people; and racial prejudice. The last factor is particularly significant in large cities, where present and prospective public housing tenants are almost all black. For example, on December 31, $1972,82 \%$ of the public housing tenants in Chicago were black; $94 \%$ of the tenants in the city's public housing not solely for the elderly were black. Chicago Housing AuTHORITy, 1972 Annual Statistical RePort Table 12. The comparable figures for Newark, N.J., as of March 31, 1970, were $71 \%$ (an additional $15 \%$ were Spanish-speaking) and $74 \%$ (plus 15\% Spanish). Housing Authority of the City of Newark, ANNUAL REPORT 1970, at 59 .

11 One major factor that leads to the construction of public housing in slum areas is the statutory limitation on the cost of the housing construction. 42 U.S.C. $\$ 1415(5)$ (1970). Because of high land costs throughout a city, housing authorities were often not able to comply with the cost limitations unless large high-rise projects were built on small plots of land in slum areas, where land costs were somewhat lower. See Natronal Comm'n on Urban Problems, supra note 3, at 123-24; Public Housing, supra note 5, at 652. But of. 42 U.S.C. \& 1415(11) (1970), which proscribes the construction of high-rise elevator projects for families with children unless there is no practical alternative. 
housing - the ghetto residents themselves. ${ }^{12}$ Plaintiffs in these actions generally contended that the equal protection clause of the fourteenth amendment or various federal statutes would be violated by construction of the housing in the ghetto. They argued that when existing public housing is found primarily in . black neighborhoods and is overwhelmingly occupied by blacks, and the new housing to be built in the ghetto would likely be occupied by blacks, ${ }^{13}$ the resulting perpetuation of racially segregated residential patterns in the city was unlawful. These plaintiffs generally sought either to enjoin construction of the project altogether, or to force the local administrators to build in a white or racially mixed neighborhood. Since the housing program was designed to benefit low-income families, efforts by the very people who were to live in the housing to block its construction were a rather staggering development.

In an important sense, then, the lawsuits brought by one group of residents of any ghetto pitted it not only against the local housing authority and other local political interests, but also against other groups of slum residents who preferred public housing and to whom the constitutional and statutory problems of segregated residential patterns were less important than decent housing. If these conflicting interests were the only ones to be considered in an injunctive action brought by some of the ghetto's residents against the housing authority, judges would have enough difficulty in shaping truly equitable remedies. When other interests are brought into play-those, for example, of the Department of Housing and Urban Development (HUD), which administers the entire public housing program, and of the myriad institutions $^{14}$ which interact with the local housing authority (LHA $)^{15}$ - the equities become increasingly difficult to determine. Consequently, creating a remedy that takes all of the divergent interests into consideration and which effectively binds all participants to the court's order is a herculean task. ${ }^{16}$ This

12 Of course the slum neighborhood, like any other, is composed of individuals with diverse interests and goals. Opposition to public housing in the slum grew as a part of the larger wave of black activism of the 1960's. While some ghetto residents went to court to fight public housing for many reasons, it cannot be gainsaid that others would have preferred to avoid controversy and to allow construction of the housing. See, e.g., notes 135-38 infra \& accompanying text.

${ }^{13}$ E.g., the court in Gautreaux v. Chicago Housing Authority, 296 F. Supp. 907, 909 (N.D. Ill. 1969), observed that $90 \%$ of the tenants in the housing authority's projects and $90 \%$ of the people on the 13,000 person waiting list were black.

${ }_{14}$ Institutions have been defined as "established laws and organizational structures, their rules, their interrelations, and the entrenched patterns of behavior built around them." A. Downs, Urban Problems and Prospects 1 (1970).

15. See notes 20-25 infra \& accompanying text.

${ }^{16}$ Nevertheless it is almost a truism of American jurisprudence that the "exist- 
Comment will explore the difficulties inhering in this task, and will conclude that it is at best unlikely that any court-fashioned remedy can both consider all of the competing interests ${ }^{17}$ and be effectively implemented. In order first, however, to provide an overview of the public housing program, it will be necessary to examine the major provisions of the Housing Act of 1937.

\section{The Housing Acr of 1937}

The two major elements of the public housing program established by the Housing Act of 1937 are the organizational structure and the financial scheme. The former includes the creation, by local governing bodies, of local housing authorities (LHA's) whose function is to plan, develop, own and manage public housing. ${ }^{18}$ The latter may involve debt financing by the federal government ${ }^{19}$ and subsidization of the LHA's' expenditures for normal operations of its housing.

\section{A. Organizational Structure}

\section{Statutory Provisions}

The Housing Act provides for the establishment of local housing authorities to supply community centered administration. ${ }^{20}$ The LHA can be any governmental entity whose creation is "authorized"21 by the state in which it operates. In practice, LHA's have generally been quasi-independent agencies established by local governments pursuant to state enabling legisla-

ence of a statutory right implies the existence of all necessary and appropriate remedies." Sullivan v. Little Hunting Park, Inc., 396 U.S. 229, 239 (1969) (dictum).

${ }^{17}$ At the minimum, these interests include HUD, the local housing authority, city hall, plaintiffs, and slum residents who want public housing constructed regardless of the racial concentration issue. The last group is almost never a party to an action against a local housing authority, but an equitable court order clearly must give consideration to its members' need for decent housing. A statement made by Mr. Justice Douglas in another context is relevant:

The qualities of mercy and practicality have made equity the instrument for nice adjustment and reconciliation between the public interest and private needs as well as between competing private claims.

Hecht Co. v. Bowles, 321 U.S. 321, 329-30 (1944) (dictum).

1842 U.S.C. $\& 1402$ (11) (1970). LHA's can also serve as cities' urban renewal agencies. 42 U.S.C. $\S 1460(h)(1970)$. Their functions with regard to urban renewal would be different from their public housing functions, and far more complex. 42 U.S.C. $\S \S 1451-55$ (1970), as amended, 42 U.S.C. $\S \S 1451-55$ (Supp. II, 1972). An analysis of urban renewal is beyond the scope of this Comment.

1942 U.S.C. $\$ 1410$ (1970), as amended, 42 U.S.C. $\$ 1410$ (Supp. II, 1972).

${ }^{20} 42$ U.S.C. $\$ 1402$ (11) (1970).

${ }^{21} \mathrm{Id}$. 
tion. ${ }^{22}$ Neither preliminary planning loans ${ }^{23}$ nor debt financing ${ }^{24}$ from the federal government can be made available to an LHA without the approval of the local governing body. When combined with state statutes, these requirements give local governments the power to determine whether LHA's will exist in their communities at all, and if so when projects may be built. ${ }^{25}$

This power is rather awesome when two additional factors are considered. First, opposition is likely to arise whenever a public housing project is proposed for a community. ${ }^{26}$ Second, the well documented suburban aversion to population growth of any sort, particularly strong when the growth is due to an influx of indigent families, ${ }^{27}$ tends to strengthen the local desire to use the statutes to exclude housing projects from the suburbs altogether. Suburban municipalities are often geographically small and socially homogeneous; thus, "community" opposition to a housing project often means opposition throughout the municipality. Local politicians have responded in the expected fashion: they have often simply refused to allow the creation of LHA's in their community, thus precluding the possibility of any public housing being built. If the locality is included in the jurisdiction of a county or metropolitan housing authority whose creation it could not control, the municipal government may exclude public housing by refusing to sign the cooperation agreement. ${ }^{28}$

${ }^{22}$ See, e.g., N.J. STAT. ANN. $\$ 55: 14 A-4$ (1964) (creation of LHA by county or municipal government). But see N.Y. PuB. Hous. Law $\$ \S 400-539$ (McKinney Supp. 1973) (creation of LHA's by state government). Cf. PA. STAT. ANN. tit. 35, § 1544 (1971) (creation of LHA by county or municipal government or by the governor).

${ }^{23} 42$ U.S.C. $\$ 1415(7)(a)(i)$ (I 970$)$.

${ }^{24} 42$ U.S.C. $\$ 1415(7)(\mathrm{b})(\mathrm{i})(1970)$. The contract is called a cooperation agreement. The LHA must show that there is a need for low-rent housing that is not being met by the private sector. 42 U.S.C. $\S 1415$ (7)(a)(ii) (1970). Further, the LHA must demonstrate that a relocation assistance program meeting federal standards will be provided, and that "decent, safe, and sanitary dwellings will be available to displaced persons" at rentals they can afford and in locations accessible to their jobs. 42 U.S.C. $\$ \$ 4625(c)(3), 4630(3)$ (1970).

${ }^{25}$ For example, consider the factual circumstances of Lawrence v. Oakes, 361 F. Supp. 432 (D. Vt. 1973) and Mahaley v. Cuyahoga Metropolitan Housing Authority, 355 F. Supp. 1245 (N.D. Ohio 1973). Of course where state law does not give the municipality the sole right to create an LHA, see note 22 supra, the local government will still be able to exclude public housing by using the federal statute alone.

${ }^{26}$ See notes 9-12 supra \& accompanying text.

${ }^{27}$ See, e.g., A. Downs, supra note 14, at 82-83; R. Wood, Suburbia 217-21, 253-55 (1958). For statistics on the homogeneity of the nation's suburbs, see Note, The Constitutionality of Local Zoning, 79 YALE L.J. 896-97 \& n.2 (1970).

${ }^{28}$ Note 24 supra. However, a bill has recently been introduced in Congress to prohibit states and political subdivisions from discriminating against low and moderate income housing in the exercise of their powers over zoning, planning, sub- 


\section{Judicial Interpretation of the Cooperation Agreement}

This system of local legislative control over public housing was directly challenged in Mahaley $v$. Cuyahoga Metropolitan Housing Authority. ${ }^{29}$ Plaintiffs, the class of "all tenants and applicants for low-income [public] housing" in the greater Cleveland area, contended that the cooperation agreement requirement is unconstitutional and a violation of the Civil Rights Act of 1964. They claimed that the statute "permits and encourages the governing bodies of local municipalities to control the acceptance of low rent housing and has directly led to the containment of low rent housing . ..."30 Relying on James $v$. Valtierra ${ }^{31}$ and dicta from Dandridge v. Williams, ${ }^{32}$ a three-judge court rejected the constitutional claims.

On remand, however, Chief Judge Battisti held that the statute had been "used ... as a tool to perpetuate segregation in violation of 42 U.S.C. $\S 1983 . " 33$ He reasoned that in recognition of the clear need for public housing in the suburbs, ${ }^{34}$ the failure of the defendant to take even preliminary steps toward signing cooperation agreements violated, inter alia, the Civil

division controls, building codes or permits, or other land use controls affecting undeveloped areas within metropolitan areas. This would be enforced by the Attorney General or by private citizens harmed by such discrimination. Political subdivisions that submit plans for inclusion of low and moderate income housing would receive priority under federal assistance programs. H.R. 11704, 93d Cong., 1st Sess. (1973).

29355 F. Supp. 1245 (N.D. Ohio), an remand, 355 F. Supp. 1257 (N.D. Ohio 1973).

${ }^{30}$ Id. at 1247 .

31402 U.S. 137 (1971). James upheld a California constitutional provision requiring that no public housing project could be built in any municipality until the project was approved in a community referendum. But see Hunter v. Erickson, 393 U.S. 385 (1969) (ordinance requiring referendum approval of any measure regulating land use on racial basis but not of other measures denies equal protection). Cf. Cornelius v. City of Parma, 42 U.S.L.W. 2213 (N.D. Ohio, Sept. 27, 1973).

32397 U.S. 471,485 (1970). There the Court stated that instead of the strict scrutiny test, "[i]n the area of economics and social welfare, .... [the] 'reasonable basis' " test for an equal protection violation would apply. But see Shapiro v. Thompson, 394 U.S. 618, 634 (1969) (strict scrutiny test applied when constitutional right to travel interstate infringed). In Mahaley Judge Lambros dissented from the threejudge court's majority opinion, pointing out that federally assisted housing programs that are not for indigents do not require local approval, while those that are do. 355 F. Supp. at 1255.

33355 F. Supp. at 1259.

${ }^{34}$ The factual finding that such a need existed was based largely on studies conducted by the Planning Commission of Cleveland and the Cuyahoga Metropolitan Housing Authority itself. $355 \mathrm{~F}$. Supp. at 1260 . The three-judge court had noted that four of the five defendant suburbs' populations were more than $99 \%$ white, the other, just over $95 \%$. Id. at 1252 . With regard to some of the indirect effects of segregated housing patterns such as these, see National Comm. Against DisCrimination in Housing, The Impact of Housing Patrerns on Job Opportunities (1968). 
Rights Acts of 1964 and $1968 .^{35}$ Consideration was also given to the national policy of dispersing public housing throughout diverse parts of urban areas. ${ }^{36}$ In ordering the housing authority to submit a plan for construction of public housing in the county, ${ }^{37}$ the court made it clear that it would attempt to induce suburban public housing developments.

Mahaley provides the major interpretation of the cooperation requirements of the Housing Act. ${ }^{38}$ In denying the constitutional challenge, the court only invited suburban municipalities to find more creative ways to avoid judicial intervention. The cooperation agreement requirement thus remains a major impediment to integration of the suburbs through public housing construction. If public housing is ever to aid in integration of the metropolitan area, it will be limited to the boundaries of the major cities. In this regard, the site selection policies of LHA's are a vitally significant determinant of whether segregated housing patterns will be perpetuated. ${ }^{39}$

\section{B. Financing ${ }^{40}$}

A second aspect of the Housing Act which also contributes to the administrative pressures bearing upon the LHA is the scheme of funding provisions. Although conceived with a view toward amicable federal-local cooperation, they have never entirely fulfilled their promise. The most basic element of the financing of public housing projects is that the LHA receives money by issuing bonds which are to be repaid by the federal government. ${ }^{41} \mathrm{~A}$. subdivision of the Department of Housing and Urban Development (HUD) is responsible for entering into "annual contributions contracts" with LHA's for this purpose.

35 355 F. Supp. at 1268 . The defendants had failed to present any substantial reasons for their inaction. Id. at $1264,1266$.

${ }^{36} I d$. at 1260-63, 1267. See also A. Downs, supra note 14, at 45-50, 60-69; National Advisory Comm'n on Civil Disorders, Report 406-07 (Bantam, ed., 1968).

37355 F. Supp. at 1269.

${ }^{38}$ See also Lawrence v. Oakes, 361 F. Supp. 432 (D.' Vt. 1973), a similar case rejecting a challenge to the local cooperation agreement requirement of another statutory model, the leased housing program, 42 U.S.C. § $1421 \mathrm{~b}(\mathrm{a})(2)(1970)$.

${ }^{39}$ Municipalities in some states have absolute control over the creation of LHA's. See note 22 supra. The question whether refusal to create an LHA in the face of a clearly shown need for low-rent housing would be an equal protection violation raises issues that are closely akin to those in the Mahaley case, but it has never been litigated.

${ }^{40}$ Because the primary concern of this Comment is enforcement of injunctive orders in actions brought against LHA's, to which LHA financing relates only secondarily, financing will not be discussed in great detail.

4142 U.S.C. § 1410 (1970), as amended, 42 U.S.C. \$ 1410 (Supp. II, 1972). 
The contracts are to provide for uniform annual payments over a maximum period of sixty years. ${ }^{42}$ Construction costs are limited to a statutory ceiling. ${ }^{43}$ HUD may also make preliminary loans to LHA's to assist in the earliest stages of housing development, and may also provide an LHA with a large cash grant for housing construction as an alternative to debt financing. ${ }^{44}$

To cover operating expenses, the LHA charges its tenants rent. If an LHA is running an operating deficit, it can be subsidized by HUD. ${ }^{45}$ Since income ceilings must be established for admission to the housing, ${ }^{46}$ and no tenant family may be charged more than one-quarter of its income as rent, ${ }^{47}$ operating deficits are fairly common.

The LHA must also be given an exemption from payment of all property taxes. In lieu of the payment of these taxes, the LHA must pay up to ten percent of its annual shelter rent receipts to the municipality. ${ }^{48}$ This payment is to be used by the municipality to defray the costs of providing services to the residents of the public housing.

Thus in practice, the financing of a housing project generates additional complexities in the local housing arena. The LHA must constantly deal with pressures from city hall and the regional and central offices of HUD. A myriad of applications must be filed even to qualify for loans, grants, and annual contributions. ${ }^{49}$

\section{Public Housing Site Selection}

A local housing authority is statutorily permitted to choose any site within its jurisdiction as the location for a low-rent housing project. It must first show that the need for low-rent housing has not been met through the private sector. ${ }^{50}$ Since the typical city will have many neighborhoods of diverse socioeconomic characteristics, the LHA's discretion is quite broad.

4242 U.S.C. $\S \S 1403,1410$ (c) (1970), as amended, 42 U.S.C. § 1410(c) (Supp.

II, 1972).

4342 U.S.C. $\S 1415(5)$ (1970). See note 11 supra.

4442 U.S.C. $\$ \S 1409,1411(1970)$.

4542 U.S.C. $\S 1410$ (a) (1970).

4642 U.S.C. $\$ 1410$ (g) (1970).

4742 U.S.C. § 1402(1) (Supp. II, 1972), amending 42 U.S.C. § 1402(1) (1970).

4842 U.S.C. $\$ 1410$ (h) (1970).

49 See, e.g., National Comm'n on Urban Problems, supra note 3, at 122, for a chart showing 45 steps involved in the processing of a public housing financing application. Even if there are no political problems, all deadlines are met by the LHA, and the quality of the proposal is acceptable, the process will still average 305 days. Of course, these three conditions do not always exist.

so 42 U.S.C. § $1415(7)(a)(i i)(1970)$. 
Consequently, if the LHA were given a free hand in determining where public housing was to be built, it could play an important social role-by integrating housing patterns, by maintaining segregation, or by placing the housing and its indigent occupants far from the city's business and residential areas or adjacent to them. Of course, LHA's normally do not have such autonomy. Political pressures exerted by HUD, the city council, and the city's various special interests substantially contribute to the final site determination. While it is obvious that these factors always affect an LHA's site selection, ${ }^{51}$ they are not factors 'recognized by the Housing Act. It speaks only in terms of the need for low-rent housing. ${ }^{.2}$ When site selection has been challenged, courts have traditionally looked only to the strict statutory criterion of need, and have therefore granted the LHA very broad discretion in its nominally objective decision. ${ }^{53}$ Only in the last five years have courts begun seriously to look at factors, other than need, which may have influenced a housing authority's site selection decision. One extremely significant factor-race-has been at the center of one state court decision and a series of federal court decisions involving statutory and constitutional challenges to site selections made by LHA's. In a reversal of the previous grant of broad discretion given LHA's, the courts in these cases carefully scrutinized the LHA decisions and often struck them down. This presented a rather unusual development for administrators of public housing programs, many of whom had operated for years on the assumption that the racial intent and effect of their site selection decisions were unreviewable. ${ }^{54}$

\section{A. The Failure of Injunctive Relief: $A$ Model}

These recent cases, however, suffer from one major shortcoming. The mechanism created by the housing statute for the

${ }^{51}$ See text accompanying note 87 infra. For an explication of some of the pressures brought to bear in the parallel urban renewal situation, see H. KAPLAN, URBAN Renewal Politics 39-60, 135-64 (1963).

5242 U.S.C. $\$ 1415(7)(\mathrm{a})(\mathrm{ii})(1970)$.

${ }^{53}$ See, e.g., Thompson v. Housing Authority, 251 F. Supp. 121, 124 (S.D. Fla. 1966); Varnadoe v. Housing Authority, 221 Ga. 467, 469, 145 S.E.2d 493, 495 (1965); Stockus v. Boston Housing Authority, 304 Mass. 507, 512-13, 24 N.E.2d 333, 337 (1939); Lennox v. Housing Authority, 137 Neb. 582, 592-93, 290 N.W. 451, 458-59 (1940); Philbrook v. Chapel Hill Housing Authority, 269 N.C. 598, 606, 153 S.E.2d 153, 159-60 (1967); Blumenschein v. Housing Authority, 379 Pa. 566, 572-73, 109 A.2d 331, 334-35 (1954); appeal dismissed, 350 U.S. 806 (1955).

${ }^{54}$ Until the issuance in 1962 of Exec. Order No. 11,063, 3 C.F.R. $§ 652$ (1959-63 Comp.), 42 U.S.C. $\S 1982$ (1970), which proscribed tenant selection in federally supported housing projects on the basis of race, many LHA's completely segregated 
construction of public housing, when combined with the intensely political ${ }^{55}$ nature of an agency whose product-low-rent housing-can lead to the controversial result of integrating white neighborhoods, ${ }^{56}$ substantially decreases the likelihood that court-devised remedies will result in construction. This conclusion is compelled from an analysis of both the kind of relief that a court can grant when an LHA's site selection policies are challenged and the likely response that the relief will elicit from the institutions in the public housing arena.

In a site selection case, three types of injunctive orders are available to a district judge who finds a constitutional or statutory infringement of plaintiffs' rights. The first is the negative injunction: "Do not build public housing on this site." The second is the less common affirmative injunction: "Build housing on this site without delay." Although institutions such as HUD or city council may also be placed under the order, these two forms of relief are typically aimed solely at the LHA. The third form of injunctive relief - "Carry out your ministerial duties"is available only when other agencies, those with purely nondiscretionary duties, are the defendants. When such an agency violates plaintiffs' rights by unjustly refusing to cooperate with the LHA or with HUD, the court simply orders it to perform its duties.

The primary advantage of a negative injunction is its simplicity. The extent of compliance by the defendant is readily determinable and the standards of behavior expected are articulable and discrete. It is usually easier to stop a party from doing something than it is to force a party to act affirmatively. ${ }^{57}$

individual projects racially. Even after the order was issued, and up through 1966, the federal government did not attempt to apply it or any other anti-discrimination measure to site selection decisions. Note, Racial Discrimination in Public Housing Site Selection, 23 Stan. L. Rev. 63, 63-64 (1970).

55 "Political" shall be used to describe the process of conflict and accommodation that occurs among the city's institutions in their ongoing efforts to carry out policies and to reach goals. "Politics arises out of conflicts, and it consists of the activities ... by which conflict is carried on." E. Banfield \& J. Wilson, City Politics 7 (1963). While some of these conflicts are resolved in courts, most of the day-to-day conflicts occurring within a city do not get to court; rather, they are resolved through the use of the political leverage that the competing institutions are able to muster and bring to bear on the particular issue at the time the conflict arises.

${ }^{56}$ It is assumed throughout this Comment that construction of low-rent public housing outside the ghetto is an appropriate public policy. Problems arise when construction is planned within a ghetto, as well as when no construction is planned at all. It is difficult to state categorically whether construction within a ghetto is preferable to non-construction; this dilemma is raised throughout.

57 This fact has long been recognized in the context of specific performance of contracts. See, e.g., 5A A. Corbin, Contracts $§ 1138$, at 106 (1964):

Although there may be no serious difficulty in compelling a defendant to 
Since the defendant knows the standard of compliance, the court's contempt power will probably be effective. ${ }^{58}$

Opposed to the inherent advantages of a negative injunction, however, is the fact that by its very nature it cannot result in public housing construction. By its terms, it can only stop the construction of public housing. This is hardly a desideratum for any court order. The massive waiting lists for admission to still unbuilt public housing ${ }^{59}$ prove that the need is extraordinary. Thus, while a negative injunction is easy to enforce, its enforcement will not yield the positive result of new housing.

The inverse case is promised when a court issues an affirmative injunction. If enforced, such an injunction would satisfy the primary policy goal of inducing the construction of public housing. However, affirmative injunctions, which require continuing supervision and great expenditures of judicial time and energy, are difficult to enforce ${ }^{60}$ The primary juridical reasons for this difficulty are that precise criteria for performance are hard to formulate; standards for compliance are not easy to determine when the enjoined duty is highly complex; and courts generally are not accustomed to monitoring orders that have complex social, political, and economic ramifications. ${ }^{61}$ Also, in such a complex pattern of institutional forces, it is difficult to

perform a non-continuing, ministerial act, such difficulty, sometimes approaching the insuperable, often exists in the specific performance of promises requiring the continuing performance of acts involving skill, judgment, training, and honesty....

The promised performance may be a forbearance to act instead of affirmative action; and when such is the case there is less difficulty in compelling specific performance.

${ }^{58} C f$. Gunn v. University Comm. to End the War in Viet Nam, 399 U.S. 383, 389 (1970) (dictum): "An injunctive order is an extraordinary writ, enforceable by the power of contempt."

${ }^{59}$ E.g., in Chicago 13,000 persons were on the waiting list in 1969. Gautreaux v. Chicago Housing Authority, 296 F. Supp. 907, 909 (N.D. Ill. 1969). The Atlanta Housing Authority had 30,000 persons on its waiting list in 1971. Crow v. Brown, 332 F. Supp. 382, 383 (N.D. Ga. 1971), aff'd per curiam, 457 F.2d 788 (5th Cir. 1972).

${ }^{60}$ For example, courts often refuse to grant affirmative relief in the specific performance context because of this difficulty. See, e.g., Northern Del. Indus. Dev. Corp. v. E.W. Bliss Co., 245 A.2d 431, 434 (1968); Lumley v. Wagner, 1 DeG., M. \& G. 604, 42 Eng. Rep. 687 (Ch. 1852).

${ }^{61} \mathrm{Cf}$. the dictum of Justice Holmes in Jones v. Parker, 163 Mass. 564, 566, 40 N.E. 1044, 1045 (1895) (emphasis added):

Whether [the covenant] should be enforced specifically admits of more doubt, the questions being whether it is certain enough for that purpose ... and whether a decree for specific performance would not call on the court to do more than it is in the habit of undertaking.

More to the point is the court's statement in Norwalk CORE v. Norwalk Redevelopment Agency, 395 F.2d 920, 930 (2d Cir. 1968) (dictum): "An affirmative form of relief, such as an order requiring the construction of low-income housing, . . . would necessarily involve the court in areas foreign to its experience and competence." 
be entirely certain of the identity of the proper defendants in a contempt proceeding. ${ }^{62}$

In addition, there may be less apparent reasons for judicial reluctance to wield the contempt power. A sensitive judge may feel uneasy about his position as judge and jury in a proceeding in which his integrity and position have been challenged. Mr. Justice Black has noted:

When the responsibilities of lawmaker, prosecutor, judge, jury and disciplinarian are thrust upon a judge he is obviously incapable of holding the scales of justice perfectly fair and true $\ldots .^{63}$

Also, when a federal judge enjoins a state governmental agency, the delicacy of tenth amendment considerations may be invoked.$^{64}$ Finally, problems of enforcement are compounded in the public housing context by the fact that the housing statute prescribes a long and demanding series of steps that must occur before an LHA can build housing even if it is acting in the best of faith. ${ }^{65}$

Despite their seeming enormity, however, these reasons do not alone explain why affirmative injunctive relief often fails to result in public housing construction. The political ecology of the city in which the court and the LHA operate ${ }^{66}$ also helps to determine the probable response to an affirmative court order.

The need for an affirmative injunction arises only when the LHA has independently made a prior decision not to build in the location in which the court decides housing must be built. Unless the LHA's policies have changed since the suit was brought and the external institutional pressure under which it must operate has abated, the LHA will resist the court's order

${ }^{62}$ Housing construction requires the cooperation and approval of so many agencies-zoning agency, planning board, building inspector, health board, water and electricity companies, and occasionally the street department-that judges may believe it would be impossible to prove that the chairman of the LHA board or the president of the city council is actually responsible for the delays. The courts are perhaps concerned with looking foolish if they attempt to fine or imprison a powerful administrator and then learn, after fighting through the bureaucratic maze surrounding public housing, that an obscure official in charge of a very minor part of the construction process is equally culpable.

${ }^{63}$ Green v. United States, 356 U.S. 165, 199 (1958) (Black, J., dissenting). See also Craig v. Hecht, 263 U.S. 255, 279 (1923) (Taft, C.J., concurring).

${ }^{84} C f$. R. Goldfarb, The Contempt Power 273-79 (1963).

${ }^{65}$ See notes $20-25,40-49$ supra \& accompanying text.

${ }^{66}$ While institutional interrelations are obviously not identical in all cities, this Comment will analyze the political problems of enforcement of injunctions without regard to the nuances of any one city's politics. 
unless forced to comply. ${ }^{67}$ In addition, once the LHA has established itself as a power in the community, by successfully developing a local public housing program, the political situation faced by a court that is trying to force the LHA to follow certain orders is one in which, according to one commentator, the well recognized autonomy of public authorities is reinforced by the functional specificity of their tasks. ${ }^{68}$ Because of its narrow functional responsibilities, the authority does not interact significantly with those institutions (here, the judicial system) which cannot affect its success:

$[T]$ he channels of political influence are altered and the effective access of various groups modified .... . [T] he authority looks [only] to the governmental leaders and investment circles primarily able to affect its discretion, and calculates policy and tactical maneuvers accordingly. ${ }^{69}$

Thus because the authority desires independence and power in the policy-making sphere, it joins with public and private allies within its own functional area and is able to "exercise major influence at all stages of policymaking and execution."70 These alliances will control the functional area in which they are situated; the public authority will be the policy leader, garnering support for its own plans. ${ }^{71}$ Because they have similar goals, "operating organizations in the same functional area ... are likely to engage predominantly in cooperative efforts .... Functional cooperation is particularly likely to develop along vertical lines-i.e., among local, state and federal agencies in the same functional area."72 When this cooperation predominates, two results are likely to follow. First, in terms of defining goals and implementing policies, the functional subsystem will be relatively independent of the balance of the city's political system. Second, there will be very little opportunity for nonallied interests (such as courts and litigious ghetto residents) to

${ }^{67}$ There may be a special reluctance to obey orders which involve emotionally explosive subjects. Cf. factual circumstances of United States v. Barnett, 376 U.S. 369 (1964). In the area of labor injunctions, such actions are common. See C. Swayzee, Contempt of Court in Labor Injunction Cases 35-37 (1968). Cf. note 77 infra.

${ }^{68} \mathrm{~J}$. Doig, Metropolitan Transportation Politics and the New York Region 7-8 (1966).

${ }^{69} I d$. at 8 (footnote omitted).

${ }^{70} I d$. at 10 .

${ }^{71} I d$.

${ }^{72}$ Id. at 233. 
shape policies. These results are even more likely to obtain in a political subsystem such as public housing, where "the operating organizations are relatively free of direct policy and budgetary control by general-government leaders" of the city. ${ }^{73}$

When a court orders an LHA to act, then, it is often doing so in the context of an extremely well organized system whose parts are dependent upon, and will fight to preserve, current operating procedures. The court is intruding upon those operating procedures when it issues an affirmative injunction. The procedures are built around a "structure of organized interests, which have carved out roles and developed stable relationships with each other. These interests respond defensively to efforts to alter policy whenever such efforts threaten to curtail their power." 74 The court order is clearly a challenge to the power of the LHA and its allied organized interests. These interests include HUD, which wants to fund public housing; contractors for the LHA; and elected and appointed officials who support the LHA for a variety of legal and illegal reasons, and whose jobs depend in part upon continued LHA success. By threatening to take away all of their power to make decisions and to implement policy in site selection, the court is threatening the LHA and its allied interests in the most extreme manner. Thus, the defensive reaction of ignoring the court's order is to be expected.

When this occurs, the court often will not be able to rely on other city institutions to pressure the LHA and its allies into compliance with the order. Those governmental agencies and private interests that can influence the LHA often have already joined the LHA's alliance; ${ }^{75}$ enforcement of the order depends upon the cooperation or resistance generated by the LHA and all of its allies. Because of the narrow functional specificity of its tasks, the remaining, non-allied, city institutions are not able to exert influence. Unless the court, without political muscle of its own, is willing to employ its contempt power more vigorously, ${ }^{76}$ the LHA resistance will probably succeed: No housing

${ }^{33} \mathrm{Id}$. at 235. In a study of urban renewal politics, Kaplan identified the agency's independence from local budgetary control as the most important element in its overall independence. H. KAPLAN, supra note 51, at 180.

$74 \mathrm{~J}$. DoIG, supra note 68, at 240.

75 As Sayre and Kaufman pointed out, "[a]uthorities, because of the insulation shielding them, are less vulnerable [than regular city agencies] and therefore less inclined to appease the other governmental officials who exert pressure on them." W. Sayre \& H. Kaufman, Governing New York City 333 (1960). They identified the sources of this insulation as security of tenure for the authority's commissioners, fiscal independence, and administrative independence. Id. at 328-32.

${ }^{76}$ Courts have been reluctant to employ the contempt power to force LHA 


\section{will be built. ${ }^{77}$}

In the unlikely event that the LHA decides to cooperate with the court and obey the affirmative injunction, the creation of new public housing is still not certain. In the typical case, where the project is to be built in a white neighborhood and many of the prospective residents are black, spontaneous oppo-

compliance with injunctive orders. For example, in the Chicago site selection litigation, the court chose not to hold defendants in contempt despite their absolute refusal to obey the court's order to build public housing in mixed and white neighborhoods. Gautreaux v. Chicago Housing Authority, 304 F. Supp. 736 (N.D. Ill. 1969); Gautreaux v. Romney, 332 F. Supp. 366 (N.D. Ill. 1971), rev'd, 457 F.2d 124 (7th Cir. 1972); Gautreaux v. Chicago Housing Authority, 342 F. Supp. 827 (N.D. III. 1972).

In another context, despite the failure of school authorities to comply with orders issued pursuant to Brown v. Board of Education, 349 U.S. 294 (1955), contempt orders in school desegregation cases have also been rare. The Supreme Court has spoken in terms of when the desegregation plans must be implemented; yet avoidance has not led to contempt orders. See, e.g., Carter v. West Feliciana Parish School Bd., 396 U.S. 290, 293 (1970) (Harlan, J., concurring) (would allow maximum eight week timetable for desegregation); Alexander v. Holmes County Bd. of Educ., 396 U.S. 19, 20 (1969) (obligation to "terminate dual school systems at once"); Green v. County School Bd., 391 U.S. 430,439 (1968) (school desegregation plan that will work "now" must be brought forward); Hall v. St. Helena Parish School Bd., 424 F.2d 320, 324 (5th Cir. 1970) (delaying implementation of desegregation plan for four months, until the beginning of the next school year; Green apparently does not mean "now" and Alexander apparently does not mean "at once"). No contempt orders issued despite the apparent clarity of the Green and Alexander decisions and the obvious flouting of those standards. Cf. Willingham v. Pinebluff School Dist., 425 F.2d 121, 124 (8th Cir. 1970). See notes 97-102, 105-06 infra \& accompanying text.

${ }^{77}$ See notes 94-106 infra \& accompanying text.

Parallel situations suggest that the intractability of an LHA may be unusually difficult for courts to handle. For example, it is apparent from the foregoing analysis that resistance by legislatures to court orders that legislatures reapportion themselves will not normally be as successful as resistance by LHA's to court orders in the site selection area. This is so despite the intensely political nature of the entire reapportionment process. See Baker v. Carr, 369 U.S. 186 (1962). There are three reasons for this fact.

First, the standards for reapportionment, as established by the Supreme Court, are much clearer than the criteria for where and how a public housing project should be built. See Abate v. Mundt, 403 U.S. 182, 184, 187 (1971); Kirkpatrick v. Preisler, 394 U.S. 526, 528-29, 533 (1969); Swann v. Adams, 385 U.S. 440, 442, 444 (1967); Reynolds v. Sims, 377 U.S. 533, 562-77 (1964). While both kinds of court orders involve political decisionmaking, the more mathematical nature of reapportionment makes it far easier to administer. Resistance and subterfuge are thus harder to use because the court will know more certainly whether a particular plan comports with its order.

The near total insulation of LHA's, see note 75 supra, is a second reason that it can ignore a court order more easily than a legislature can. While an LHA can be influenced by only a few institutions, many of which are already allied with it, the legislature is open to pressures from all directions. The legislature may also be hurt by internal dissension and disagreement on the reapportionment issue; a successful LHA will rarely, if ever, exhibit internal disagreement on an important policy such as site selection. Cf. H. KAPLAN, supra note 51 , at 46-48. Diverse pressures on and 
sition by residents of the neighborhood will often arise. ${ }^{78}$ This will inevitably influence city hall to move in the expected manner-to oppose the project. ${ }^{79}$ Since it does not want to spend money on projects whose popularity is low and whose future may be short, despite the court order, HUD would probably perceive the project as one that ought not be funded until local conflict has been resolved. ${ }^{80}$ Thus although affirmative, unlike negative, injunctions offer the chance to fulfill the policy goal of building public housing in non-ghetto areas if they are enforced, the political environment that surrounds public housing authorities significantly decreases the chances of enforcement.

Only in a few cases limited to local agencies with purely ministerial duties can the courts be effective in stimulating the production of housing. For example, if a local official refuses to

disagreement within a legislature make it more susceptible to forced compliance with the court's order.

Finally, the court itself wields a larger and more effective arsenal when dealing with a legislature than when dealing with an LHA. Redistricting can be done at a desk, but housing cannot be built if locations are not chosen and contracts are not signed. If a legislature refuses to redistrict itself, the court can take one of several steps. It can consolidate existing districts; require that future legislative elections be at-large across the whole state; redistrict the state itself; mandate weighted voting within the legislature; or enjoin the legislature from enacting any new statutes until a reapportionment bill is passed. McDermott, Judicial Sanctions and Legislative Redistricting in Washington State, 45 WASH. L. REv. 681, 701, 706-08 (1970). However, if an LHA refuses to build housing, the court itself cannot build it; the task is physically beyond the capabilities of the court. Potentially successful remedies require an approach that may be too non-traditional for the taste of many judges.

${ }^{78}$ See, e.g., Citizens Comm. for Faraday Wood v. Lindsay, 362 F. Supp. 651 (S.D.N.Y. 1973); Forest Hills Residents Ass'n v. New York City Housing Authority, 69 Misc. 2d 42, 329 N.Y.S.2d 69, rev'd per curiam, 39 App. Div. 2d 64, 332 N.Y.S.2d 156, aff'd sub nom. Margulis v. Lindsay, 31 N.Y.2d 167, 286 N.E.2d 724, 335 N.Y.S.2d 285 (1972).

Community opposition is obviously not based solely on race. As a result of a complex set of fears centered around perceptions that social problems accompany poor people wherever they go, opposition to economic integration is also intense in many non-poor white neighborhoods. In combination with racial animus, these perceptions led to massive community opposition to a housing project supported by the LHA and proposed for construction in the Forest Hills section of Queens, New York City. See, e.g., Goodman, The Battle of Forest Hills-Who's Ahead?, N.Y. Times, Feb. 20, 1972, $\S 6$ (Magazine), at 8; id., Nov. 28, 1971, § 4, at 3, col. 3; id., Nov. 26, 1971, at 41, col. l; id., Nov. 19, 1971, at 49, col. 5; Wicker, Conflict in Queens, id., Nov. 18, 1971, at 47, col. 1; id., Oct. 30, 1971, at 19, col. 1; id., Feb. 21, 1971, at 81, col. 2. Of course, race and poverty have a high correlation in most large metropolitan areas, and opposition to poor people converges with opposition to blacks to a very great degree.

${ }^{79}$ In Chicago, it was found that anticipated opposition from constituents was one of the major reasons leading the city aldermen who represented white neighborhoods to veto any housing projects planned for their wards. Gautreaux v. Chicago Housing Authority, 296 F. Supp. 907, 910,913 (N.D. Ill. 1969).

${ }^{80}$ For an analysis of the need to consolidate local approval and to avoid signs of conflict in the urban renewal context, see H. KAPLAN, supra note 51, at 4-5, 10-14, 
issue a building permit on impermissible grounds such as race, and all other local and federal agencies approve the project, a court can easily order the permit to be issued. ${ }^{81}$ Although this order would be affirmative in nature, its enforcement is a far different matter than the enforcement of a significantly more complex order issued to an LHA. In the ministerial injunction, there are clear standards for compliance; the duty is straightforward and well defined. Furthermore, no political opposition is likely to exist around an agency whose duties are nondisçretionary.

In sum, courts appear to be ill-equipped to cope effectively with legal challenges made to LHA site selection policies by ghetto residents. The intersection of the complex housing statute and political constraints with judicially ordered injunctive relief will very likely not produce housing. ${ }^{82}$ Court orders that are enforceable are by their very terms unable to lead to housing construction. Court orders whose terms would produce housing are unlikely to be enforceable. The caprice of federal funding adds another layer of complexity. It seems therefore that courts can effectively aid the construction of public housing only in those few cases involving obstruction by an agency with purely nondiscretionary duties.

\section{B. The Gautreaux Decision}

A classic example of the inability of the judicial system to provide a meaningful remedy in the area of public housing site selection is Gautreaux $v$. Chicago Housing Authority. ${ }^{83}$ Plaintiffs in

28-36, 165-83. Kaplan noted that the major norm of the renewal system he studied was a procedural one, requiring that "conflicts be settled through informal bargaining, not through overt attacks or public agitation." Id. 167.

${ }^{81}$ See Kennedy Park Homes Ass'n v. City of Lackawanna, 436 F.2d 108 (2d Cir. 1970), cert. denied, 401 U.S. 1010 (1971) (rezoning in order to exclude an apartment project that would be occupied by blacks); Dailey v. City of Lawton, 425 F.2d 1037 (10th Cir. 1970) (refusal to rezone and issue building permit for apartments, in the midst of an area already zoned for apartments); Sisters of Providence v. City of Evanston, 335 F. Supp. 396 (N.D. Ill. 1971) (refusal to rezone to allow development of low income housing project).

${ }^{82} C f$. Banks v. Perk, 341 F. Supp. 1175, 1182 (N.D. Ohio 1972), aff'd in part $\xi^{\prime}$ rev'd in part mem., No. 72-1576 (6th Cir., Jan. 8, 1973) (dictum):

This Court is not in the business of building public housing. It is authorized

8 nly to determine whether the policies and, in general terms, the practices of

[the LHA] are in conflict with the Fourteenth Amendment ....

${ }^{83} 265$ F. Supp. 582 (N.D. Ill. 1967) (dismissal of defendant's motion for summary judgment), 296 F. Supp. 907 (N.D. Ill.) (summary judgment for plaintiffs), order issued, 304 F. Supp. 736 (N.D. Ill. 1969), aff'd, 436 F.2d 306 (7th Cir. 1970), application for stay denied, 401 U.S. 953, cert. denied, 402 U.S. 922 (1971), supplementary order issued, 342 F. Supp. 827 (N.D. Ill. 1972), aff'd sub nom. Gautreaux v. City of Chicago, 480 F.2d 
Gautreaux were the class of all black tenants in and applicants for public housing within the jurisdiction of the defendant Chicago Housing Authority (CHA). They challenged CHA's site selection policy on the ground that the placement of large projects in the city's slums had been intended to perpetuate, or had resulted in perpetuation of racially segregated residential patterns. ${ }^{84}$ An examination of the overpowering statistical evidence in combination with several crucial admissions made by CHA personnel during discovery ${ }^{85}$ and CHA's failure to present even a minimal defense persuaded the court to grant judgment to plaintiffs. ${ }^{86}$ One important factual nuance which led to the decision was that each city alderman had been granted informal veto power. Because a ninety percent black waiting list promised a black project, whenever sites were proposed in white areas, the aldermen invariably exercised their power. City council always concurred in any such vetoes. ${ }^{87}$

The order subsequently issued by Judge Austin, in response to this political interplay, was remarkable for its breadth and complexity. ${ }^{88}$ All of Cook County was divided into two sections. The "limited public housing area" was defined as that part of the county either within census tracts having at least

210 (7th Cir.), petition for cert. filed, 42 U.S.L.W. 3339 (U.S. Dec. 4, 1973) (Nos. 73-784, 785), supplementary opinion issued sub nom. Gautreaux v. Romney, 363 F. Supp. 690 (N.D. IIl. 1973). Because the first three opinions have been discussed in depth elsewhere, they will not be analyzed in detail here. See, e.g., 83 HARv. L. Rev. 1441 (1970); Note, Discriminatory Site Selection in Public Housing and Federal Judicial Response, 64 Nw. U.L. Rev. 720 (1970); Comment, Gautreaux v. Public Housing Authority: Equal Protection and Public Housing, 118 U. PA. L. REv. 437 (1970); Note, Public Housing and Urban Policy: Gautreaux v. Chicago Housing Authority, 79 YALE L.J. 712 (1970). A short interpretation of the early decisions is needed here, nonetheless, in order to lay the groundwork for an analysis of Gautreaux's progeny.

84265 F. Supp. at 583.

85296 F. Supp. at 910-13. E.g., of the 103 sites initially selected by CHA between 1955 and 1968 because of their compliance with federal and state statutory criteria, 41 , or $39.8 \%$, were in white areas. However, of the 51 sites finally approved, only two, or $3.9 \%$, were in white areas. Of these two sites, one had only 36 dwelling units, and the other, while in a $73 \%$ white census tract, was adjacent to a cluster of poor blacks and apparently very far from the white residents of the census tract. Id. at 910-11.

${ }^{86} I d$. at 913 . The court did so only on the counts in which plaintiffs had alleged intent by CHA; defendants had already been granted judgment on the counts in which no intent was alleged. $265 \mathrm{~F}$. Supp. at 584. For a critical analysis of the court's insistence that intent be alleged in order for plaintiffs to succeed on the merits, see Comment, Gautreaux v. Public Housing Authority: Equal Protection and Public Housing, 118 U. PA. L. REv. 437, 439-43 (1970).

87296 F. Supp. at 910,913 . Approval of all sites by city council was necessary under Illinois law. Ill. ANN. STat. ch. 671/2, \& 9 (Smith-Hurd Supp. 1973); 296 F. Supp. at $909-10$.

${ }^{88}$ See 304 F. Supp. at 736; Comment, Gautreaux v. Public Housing Authority: Equal Protection and Public Housing, 118 U. PA. L. Rev. 437, 443-47 (1970). 
thirty percent nonwhite population or within one mile of the boundary of any such census tract. The "general public housing area" was defined as the remainder of the county. With the exception of $1,458 \mathrm{dwelling}$ units already included within a pending public housing project, the court then ordered that no more units could be built by CHA until 700 new units were under construction or completed in the general public housing area of the county. Thereafter, at least seventy-five percent of all public housing units commenced or leased by CHA were to be in the general public housing area. To further increase the dispersal approach of the order, the court decreed that no single project could be built for more than 120 people (or, in extreme cases and with the court's permission, 240); no public housing could be built where it would result in over fifteen percent CHA housing in a single census tract; and no dwelling units above the third story of any building were to be rented to families with children. The court further ordered CHA to use its best efforts to build new public housing and to eliminate the racially segregated public housing system. ${ }^{89}$ Finally, exercise of the unit veto power by city aldermen was permanently enjoined. The entire order was made binding not only upon CHA, but upon city council as well. ${ }^{90}$ After modification requiring CHA to submit site proposals to city council in accordance with a specific timetable, the order was affirmed by the Seventh Circuit. ${ }^{91}$ The finding of racial discrimination by CHA was never challenged on any appeal. ${ }^{92}$

Gautreaux's significance lies not only in the fact that it was the first of a long series of discriminatory site selection cases, but also in the breadth of the affirmative order issued by the court. The court, in an unprecedented manner, immersed itself in the process of site selection and set up strict limitations, not fully contemplated by the statute, ${ }^{93}$ upon the sites which $\mathrm{CHA}$ could permissibly choose. It also made a conscious effort not only to end further segregation in housing patterns, but also actively to promote integration. If complied with, its order

$89304 \mathrm{~F}$. Supp. at $737-39,741$. One commentator has suggested that the remedy was properly a matter of policy, not of constitutional law, concluding:

The court in Gautreaux did resolve this policy debate, and both the direc-

tion of its resolution and the skill such resolution displays cast doubts on the wisdom of having courts, in preference to other institutions, so decide.

Note, Public Housing and Urban Policy, supra note 83, at 718-19.

${ }^{90} 304$ F. Supp. at 741. See FED. R. Civ. P. 65(d).

91436 F.2d 306, 310-11, 313 (7th Cir. 1970).

${ }^{92} \mathrm{Id}$. at 308 .

${ }^{93}$ But see 24 C.F.R. § 1.4(b)(2)(i) (1973). 
would have successfully placed small clusters of indigent black families in many white neighborhoods.

If the model of housing authority response to affirmative court orders is correct, however, the expected response to the order would be refusal by CHA and its allies to obey, and failure of the court to force compliance. In fact, this is exactly what has happened in Chicago. The veto arrangement that existed between CHA and city council attested to the presence of an alliance. CHA had support from Mayor Daley, who reacted negatively, stating that the "ruling . . . could slow up or block future public housing construction" in Chicago. ${ }^{94}$ Strong community opposition has also plagued efforts to enforce the court's order. ${ }^{95}$ Since issuance of the order in 1969, the court has been unable to devise any techniques to force $\mathrm{CHA}$ and city council to comply. As expected, the court has not used the contempt power against the defendants. ${ }^{96}$ In one innovative effort, Gautreaux $v$. Romney, ${ }^{97}$ a separate class action instituted against HUD, Judge Austin cut off funding for an entirely different federal program operated in Chicago until CHA and city coun-. cil agreed on sites which complied with the original order. The plaintiffs claimed that since it had known that it was funding an authority whose site selection was racially discriminatory, HUD had joined CHA in the creation of a racially segregated public housing system.

In formulating the remedy, however, Judge Austin went far beyond what appeared on the face of the case. He looked to HUD's interaction with the city government in another spherethe funding of the Model Cities program. ${ }^{98} \mathrm{HUD}$ had agreed to fund Chicago's 1971 Model Cities program only on the condition that the mayor and CHA sign a letter of intent to select public housing sites in white neighborhoods on a specified

${ }_{94}^{4}$ Note, Public Housing and Urban Policy, supra note 83, at $712 \mathrm{n} .1$ (quoting Chicago Tribune, Mar. 12, 1969, at 12, col. 1).

${ }^{95}$ On the ground that HUD had not filed an environmental impact statement pursuant to 42 U.S.C. $\S 4332$ (1970), one coalition of local community organizations and individuals sought to enjoin construction of the housing required by Judge Austin. Judge Hoffman held that the statement was required, but that HUD's "negative impact" statement, declaring the project would not affect the environment adversely, was sufficient. The plaintiffs had actually attempted to prove that the tenants of the public housing would probably engage in anti-social and criminal acts, thereby affecting the local "environment" adversely. This claim was rejected. Nucleus of Chicago Homeowners Ass'n v. Lynn, 2 CCH Pov. L. ReP. \ 18,063 (N.D. Ill., Nov. 21, 1973).

${ }^{96}$ For an analysis of possible reasons, see notes 60-64 supra \& accompanying text.

97448 F.2d 731 (7th Cir.), remanded, 332 F. Supp. 366 (N.D. Ill. 1971), rev'd, 457 F.2d 124 (7th Cir. 1972).

9842 U.S.C. $\S \S 3301-74$ (1970). 
schedule; HUD had been attempting to force compliance with Judge Austin's earlier order. Although the mayor and CHA did sign the letter of intent, Judge Austin noted that site selection had again fallen far behind schedule. Concluding that there had never been any real intention to comply with the schedule included in the letter of intent, he found that it had been signed solely to induce HUD to provide Model Cities funds. ${ }^{99}$ In recognizing that Model Cities was a program that city hall desired, Judge Austin was provided with a possible lever to use against both the intransigent city administration and the housing authority. Using extraordinarily strong language, ${ }^{100}$ he enjoined HUD from providing further Model Cities funds to Chicago until CHA and city hall had agreed on sites for 700 of the 1,700 public housing units included in the original letter of intent. ${ }^{101}$ His apparent hope was to use external pressure to force the city council to approve sites that would qualify for public housing under the court's original order. In this fashion, the functional alliance built around CHA could be broken.

However, the court's attempt to induce compliance with its previous order did not survive on appeal. On the grounds that the Model Cities program itself was not tainted with discriminatory action and that the district court had no power to tie funding for one program to progress in another, the Seventh Circuit reversed. ${ }^{102}$ Thus, an ambitious attempt to force compliance with the Gautreaux v. Chicago Housing Authority order was frustrated. Therefore as Gautreaux v. Romney makes clear, the inherent limitations of the judicial system prevent the courts from actively shaping social and political policy. ${ }^{103}$ Furthermore, the Chicago experience illustrates two additional facts about the probable patterns of interaction between the courts and the public housing system generally. First, even if the LHA finally acquiesces in a district court's affirmative order, remaining elements of the public housing alliance may choose to continue their opposition to the court. This will be true particularly in those contexts, similar to Gautreaux, where those institutions defy the court order not only out of allegiance to the LHA and

99 332 F. Supp. at 369.

100 The court compared city officials to southern governors who had attempted to stop school integration by standing "at the school house and the state house doors with their faces livid and their wattles flapping ..." Id. at 370 (dictum).

${ }^{101} I d$.

102457 F.2d 124, 127 (7th Cir. 1972). See 86 HARv. L. REv. 427 (1972); 17 ST. L.U.L.J. 395 (1973).

${ }^{103}$ Judge Austin did, however, succeed in spurring some action from CHA through a supplementary order suspending an Illinois statute which required city council's approval of all site selections. Gautreaux v. Chicago Housing Authority, 342 
its policies, but out of a strong feeling of self interest. In Gautreaux, the white city aldermen themselves did not want housing projects in their neighborhoods, and Mayor Daley did not want a federal court to interfere with his control over Chicago. ${ }^{104} \mathrm{Re}-$ gardless of CHA's response, then, the stakes were high from city hall's perspective. In such situations, the courts may expect continued recalcitrance.

The second conclusion to be drawn from the ongoing Gautreaux litigation is that courts are truly loath to use their contempt power in the public housing context. City council had clearly refused, for almost three years, to comply with the terms of Judge Austin's original order, ${ }^{105}$ yet no contempt decrees have issued.106 If the reluctance to use the contempt power is common, defendants will not easily be deterred from ignoring injunctions. More vigorous use of contempt might induce defendants to obey court orders. ${ }^{107}$

The Gautreaux litigation is still proceeding. In the most recent order, Judge Austin denied plaintiffs' motion for creation of a metropolitan form of relief. ${ }^{108}$ In doing so, he expressed his continuing frustration at city council's noncooperation; and for the first time he attributed to the federal government part of the blame for the lack of success attained by his orders:

$[\mathrm{N}] \mathrm{o}$ public housing has been built in this City since my order of July 1, 1969 because the municipal authorities refused to approve sufficient sites for such housing and recently because of a lack of funds. ${ }^{109}$

Chicago is unfortunately a laboratory in which the expected pattern of response to affirmative court orders has proven cor-

F. Supp. 827 (N.D. Ill. 1972), aff'd sub. nom. Gautreaux v. City of Chicago, 480 F.2d 210 (7th Cir.), petition for cert. filed, 42 U.S.L.W. 3339 (U.S., Dec. 4, 1973) (nos. 73-784, 785).

${ }^{104}$ See M. Royko, Boss (1971).

105304 F. Supp. 736 (N.D. Ill. 1969).

${ }^{106}$ The failure to wield the contempt power is a continuing mystery. Although some considerations have been suggested, notes 60-64 supra \& accompanying text, a complete explanation has never been articulated. Perhaps in its factual context, the Gautreaux court has been unable to determine the identity of the contumacious individuals in a political arena susceptible to a myriad of pressures. Unless the source of obstinance is defined, any fine or incarceration will not result in the mandated construction. See note 62 supra.

${ }^{107}$ See notes 185-87 infra \& accompanying text.

${ }^{108}$ Gautreaux v. Romney, 363 F. Supp. 690 (N.D. Ill. 1973). Cf. the court's order that a plan for metropolitan relief be devised in Mahaley v. Cuyahoga Metropolitan Housing Authority, 355 F. Supp. 1257, 1269 (N.D. Ohio 1973). In Mahaley, however, the LHA's jurisdiction was almost county-wide. OHIo Rev. Code Ann. § 3735.27 (Page 1971). In Gautreaux, the CHA did not have metropolitan jurisdiction.

${ }^{109} 363$ F. Supp. at 691 . 
rect. The LHA and its ally, city hall, have refused to cooperate and HUD has not provided funding. In sum, the court has been unable to cope with the enormous political problems embroiling its orders. The political problems in Chicago are simply too pervasive for any court to cope with effectively.

\section{Gautreaux's Progeny}

Gautreaux was followed by a series of decisions involving racially discriminatory site selection ${ }^{110}$ which also demonstrate the inability of courts to provide meaningful and effective relief. Notwithstanding the end result, the range of remedies fashioned in the later cases shows that an affirmative order such as Judge Austin's is not the only way that judges think the problems can be approached. However, if the model for housing authority response to court orders is accurate, the exact form of the court's order is irrelevant; the result, in any event, should be non-construction of public housing.

The first decision to draw significantly on Gautreaux was Hicks $v$. Weaver.111 The plaintiff class of all black residents of Bogalusa, Louisiana sought to enjoin construction of public housing on two sites on the ground that the locations would perpetuate a segregated public housing system and result in discrimination against the plaintiffs. The specific projects being challenged by plaintiffs were to be built in black neighborhoods. The failure of any whites ever to move into projects in black areas, even though the option had existed for over a year, ${ }^{112}$ was a strong indication that the projects' residents would all be black. The court therefore found that the Bogalusa Housing Authority (BHA) had "considered the racial concentration of the neighborhoods before it looked to any other factor governing the selection of sites. ... [T] sites for the location of public housing was the racial concentration of the neighborhoods." 113 The court also found that BHA

110 The same problem has arisen in the context of other federally funded housing and redevelopment programs. See, e.g., Shannon v. HUD, 436 F.2d 809 (3d Cir. 1970); Graves v. Romney, C.A. No. 19474-2 (W.D. Mo., Apr. 6, 1973); South East Chicago Comm'n v. HUD, 343 F. Supp. 62, 66-67 (N.D. Ill. 1972), aff'd on other grounds, 2 CCH Pov. L. REP., If 17,894 (7th Cir., Oct. 19, 1973).

111302 F. Supp. 619 (E.D. La. 1969). One site selection case actually predated Gautreaux, but the court did not find that the defendant housing authority had violated the constitution or the statutes. In fact, the court was convinced that the site in question-in a racially mixed neighborhood-had been selected in accord with community needs and without racial motivation. Thompson v. Housing Authority, 251 F. Supp. 121, 123-24 (S.D. Fla. 1966).

112 Prior to that time, the housing authority had had a formal policy of segregating project residents racially. $302 \mathrm{~F}$. Supp. at 623.

${ }^{113} \mathrm{Id}$. 
had chosen sites in black neighborhoods in order "to perpetuate segregation of the races in public housing. . . ."114 Relying on Gautreaux, the court concluded that defendant had violated both the equal protection clause of the fourteenth amendment and the Civil Rights Act of 1964. ${ }^{115}$ Because of its deep involvement in the Bogalusa public housing program, defendant HUD was also included in the judgment. ${ }^{16}$

The most troubling aspect of Hicks, however, was the court's remedial order, which enjoined both construction of the challenged projects and HUD funding pending further orders of the court. ${ }^{117}$ Preventing the construction and funding of ninety-eight public housing dwellings, the court eliminated the only feasible exit from a deteriorating housing environment for the city's low-income black families. ${ }^{118}$ In fashioning a truly equitable remedy, the court ought to have considered these exigencies. By vindicating an equal protection claim of plaintiffs, the court ignored the housing needs of many of Bogalusa's indigent blacks. ${ }^{119}$ In recognition of the housing authority's history, it was clear that no public housing for blacks would ever be built in white neighborhoods; the court's order ensured that none would ever be built anywhere. Consequently, in reaching a correct legal conclusion, the Hicks court failed to respond to the concomitant effect on the quality of housing available to poor blacks in Bogalusa. The order falls into the category of negative injunctions, which by their terms cannot fulfill the policy goal of construction of acceptable housing.

Shortly after Hicks $v$. Weaver was decided, the Arizona Court of Appeals unanimously held that an LHA must give consideration to the racial composition of the neighborhood in which it places a project and must follow the public mandate against perpetuating or intensifying racial segregation. The plaintiffs in El Cortez Heights Residents ES Property Owners Association v. Tucson Housing Authority ${ }^{120}$ challenged the defendant housing authority's decision to place a 120-unit project in the only middle income black neighborhood in the county when it knew that almost all potential residents would be blacks, Mex-

$114 \mathrm{Id}$.

11542 U.S.C. $\$ 2000 d$ (1970).

116302 F. Supp. at 621-23.

117 Id. at 627-28. See notes 13-14 supra \& accompanying text.

118 Assuming, that is, that Bogalusa follows the norm of private sector refusal to build low-cost housing for indigent occupants without some form of federal subsidy.

119 The named plaintiff, Robert Hicks, was not one of Bogalusa's indigent citizens. He owned a home and earned too much to be eligible for public housing. 302 F. Supp. at 620 .

12010 Ariz. App. 132, 457 P.2d 294 (1969). 
ican-Americans and Indians. ${ }^{121}$ The challenge was based on the theory that the selection of a black neighborhood for the project would inevitably perpetuate the isolation of the three racial minorities. ${ }^{122}$ Relying on the fourteenth amendment, the Civil Rights Act of $1964,{ }^{123}$ an executive order, ${ }^{124}$ and federal regulations, ${ }^{125}$ the court held that the housing authority had violated plaintiffs' rights by failing to give careful consideration to the racial composition of the neighborhood in which it planned to place the project. In order to follow the mandate of the regulations and statute and to "work to de-isolate racial and minority groups,"126 the court also ordered the LHA to give the same consideration to all future projects. However, while stating that the placement of a project in a black neighborhood "creates strong doubts" about its legality, the court expressly did not rule that such a result is illegal per se. ${ }^{127}$

A determination that the housing authority would have to consider the racial effects of site selection for any future projects, however, accomplishes little if the LHA chooses to ignore it. A ruling aimed at the informational inputs of the process of site selection rather than its ultimate result still leaves the LHA a great deal of unreviewable discretion. The LHA can easily show that it "considered" racial effects but nevertheless decided to place a project in the black area. Additionally, even if the LHA ultimately decided to place the project in a white neighborhood, strong community opposition would probably result. Unless the LHA were then truly committed, it would probably be induced to retreat to a black neighborhood. Thus the El Cortez remedy also fails to fulfill the goal of satisfactory housing construction.

The conflicting interests that filter through the courts' opinions in Gautreaux, Hicks and El Cortez were poignantly recognized by the Court of Appeals for the Third Circuit in Croskey Street Concerned Citizens $v$. Romney. ${ }^{128}$ Plaintiffs sought to enjoin the construction of a 100-unit public housing project for the elderly in a north Philadelphia area which was alleged to be

${ }^{121}$ Id. at 133,457 P.2d at 295.

122 Id.

${ }^{123} 42$ U.S.C. $\S 2000 d(1970)$.

124 Exec. Order No. 11,063, 3 C.F.R. § 652 (1959-1963 Comp.), 42 U.S.C. § 1982 (1970).

12524 C.F.R. $\S 1.4$ (1973).

12610 Ariz. App. at 134, 457 P.2d at 296. Despite the conventional theory that the Constitution is colorblind, the court expressed its opinion that "the Constitution is very color conscious" in contexts in which a state agency's actions would inevitably lead to either segregation or integration. Id.

127 Id. at $135,457 \mathrm{P} .2 \mathrm{~d}$ at 297.

128459 F.2d 109 (3d Cir. 1972), aff'g 335 F. Supp. 1251 (E.D. Pa. 1971). 
over ninety-five percent black. ${ }^{129}$ The primary theory advanced by the plaintiffs was that HUD had not complied with the site selection standards required by the Civil Rights Acts of $1964^{130}$ and $1968^{131}$ nor with the procedures mandated by the Third Circuit in Shannon $v$. HUD. ${ }^{132}$ As in prior site selection cases, plaintiffs alleged that the project would maintain or intensify existing racially segregated housing patterns. Because plaintiffs failed to show that they would suffer irreparable injury if the injunction were denied, ${ }^{133}$ and although it found that HUD had failed to satisfy Shannon entirely, the district court, denying the injunction, concluded that HUD had complied sufficiently with the substantive requirements of that ruling.

In affirming the district court's holding, the court of appeals showed a fine sensitivity to the conflicts that inevitably arise whenever one group of neighborhood residents sues on behalf of all and purports to represent the views of all. The court sternly remarked that the 2,000 people waiting for construction of the housing would be "grievously injured" by an injunction and that the plaintiffs' efforts had thus far been "patently against the public interest."134 In a perceptive concurring opinion, Judge Aldisert went beyond the reprimand of the court. He argued:

Depriving the elderly of this facility, or even delaying access thereto, is to me an important, if not the most important, consideration of these entire proceedings. I am not at all convinced that the peculiar interests of the elderly are properly represented by the plaintiff class or by the intervenor, whose private and personal causes entail broader considerations which may, at least in these proceedings, directly conflict with the immediate interests of the potential residents of the Croskey project. $^{135}$

\footnotetext{
129335 F. Supp. at 1253.

13042 U.S.C. $\S 2000 \mathrm{~d}(1970)$.

13142 U.S.C. $\S \S 3601,3603-04$ (1970).

132436 F.2d 809 (3d Cir. 1970). The Shannon court stated:

We hold, however, that [HUD] must utilize some institutionalized method whereby, in considering site selection or type selection, it has before it the relevant racial and socio-economic information necessary for compliance with its duties under the 1964 and 1968 Civil Rights Acts.

Id. at 821 (emphasis added).

133335 F. Supp. at 1253, 1256, 1258.

${ }^{134} 459$ F.2d at 111 (dictum).

${ }^{135} \mathrm{Id}$. at 113. See South E. Chicago Comm'n v. HUD, 343 F. Supp. 62, 67 (N.D. III. 1972) for an expression of similar qualms by Judge McLaren in the context of a $\S 236$ housing project, 12 U.S.C. \& 1715z-1 (1970).
} 
Without finding a way out of the dilemma, Aldisert went on to point out the difficulties in fashioning a remedy when two public benefits conflict-placing public housing in areas other than the city's ghettos and providing at least minimally adequate housing to elderly citizens who could not otherwise afford it. In the case presented to the court, the satisfaction of one goal would almost automatically frustrate the other. ${ }^{136}$

Judge Aldisert thus appears to be the first fully to articulate the conflict of interest issue. In a diverse urban neighborhood, it is nearly impossible for one group to represent the views of all. ${ }^{137}$ The fact that everyone in the neighborhood is poor and black does not necessarily lead them to agree on policy goals and tactics. In Croskey Street, the size of the waiting list alone indicated that many families in the neighborhood considered access to decent housing to be more important than racial considerations, ${ }^{138}$ thus, to the extent that they were members of the class which the plaintiffs claimed to represent, the suit did not reflect their views. Although Judge Aldisert did not solve the problem, his recognition of the many conflicts in this area was an important insight.

Another case in which a housing authority's selection of a public housing site was challenged is Blackshear Residents Organization v. Housing Authority. ${ }^{139}$ Plaintiffs were members of the class of all blacks and Mexican-Americans in Austin, Texas, who were eligible for admission to housing projects administered by the Austin Housing Authority (AHA). They sought to enjoin further construction and funding of project TEX 1-9, on the grounds that it would further the racially segregated public housing system created in Austin by AHA and HUD. ${ }^{140}$ The

${ }^{136} 459$ F.2d at 112-14. Judge Aldisert pointed out that four nominal guardians of the public interest were involved in the case: (a) the defendant government agencies, "de jure public guardians," (b) plaintiffs, (c) plaintiffs' legal counsel, and (d) the intervenor Resident Advisory Board, claiming to represent everyone eligible for public housing in Philadelphia. Id. at 114 . Conspicuous by their absence were the potential elderly residents of the challenged project.

${ }^{137}$ In recognizing this fact, there is some question whether such a suit is maintainable as a class action. FED. R. CIV. P. 23(a)(4).

${ }^{138}$ It is not suggested that the ignorance of the people on the waiting list concerning their legal rights should totally preclude litigation by other neighborhood residents who, aided by counsel, see violations of the statutes and the Constitution by the LHA. Clearly, court challenges are one of the few ways to affect an LHA's behavior. However, neither plaintiffs nor judges ought to be so myopic as to forget that an entire set of interests is involved, even though only a few may be presented by counsel in the courtroom.

139347 F. Supp. 1138 (W.D. Tex. 1972).

${ }^{140} \mathrm{Id}$. at 1140. Other allegations of the complaint, not relevant here, included the creation of a segregated public housing system through discriminatory tenant 
court was forced finally to conclude that the "obviously segregated patterns of occupancy and site location in the Austin public housing system were brought about in large measure through the conscious design of the Housing Authority and with the knowing approval of HUD . . ."141 It determined further that the procedures used by AHA and HUD were inadequate to demonstrate proper consideration and implementation of the national policy of desegregated housing, as expressed in statutes and regulations. ${ }^{142}$ In fact, HUD had failed to meet its own standards to the effect that public housing could not be built in a racially impacted area "unless there is a clear, factually substantiated showing that no other acceptable site or sites are available outside the area." 143 The court therefore held that the selection of the site for project TEX 1-9 must be set aside, since neither AHA nor HUD had complied with the statutory requirements. For future site selections, the court required "procedures ... showing the racial factors [AHA and HUD] consider and the factual basis upon which they act in selecting and approving project sites."144

The court's remedy was simple. It enjoined all construction and funding of the project until the defendants complied with the court's guidelines and further gave defendants the burden of proving either that the project was not in an area of racial concentration or that no other sites were available. ${ }^{145}$ For all practical purposes, then, the court cut off funding ${ }^{146}$ until AHA chose to relocate the project in a white or mixed neighborhood. The anticipated problems with the Blackshear remedy are therefore similar to those actually encountered in Hicks $v$. Weaver. ${ }^{147}$ The court issued a simple negative injunction whose abrogation was conditioned upon changes in AHA's site selection policy. In doing so, the court failed to consider the unrep-

assignment policy; a denial of due process through HUD's failure to articulate its reasons for denying plaintiffs' administrative complaint; and a claim that the site was not decent, safe, and sanitary, as required by the Housing Act of 1937, 42 U.S.C. §§ $1401,1402(I)(1970)$. Id.

${ }_{141}$ Id. at 1142 .

${ }^{142} I d$. at $1145-48$. The court cited 42 U.S.C. $\$ \$ 2000 \mathrm{~d}, 3601,3608(\mathrm{~d})(5)$ (1970); 24 C.F.R. § 1.4(b)(2)(i) (1973); and Shannon v. HUD, 436 F.2d 809 (3d Cir. 1970). The court expressly did not reach the constitutional issue. $347 \mathrm{~F}$. Supp. at 1146.

${ }^{143} I d$. at 1146.

$144347 \mathrm{~F}$. Supp. at 1149 . The court suggested nine racial, social, and historical criteria that AHA and HUD would be wise to consider in selecting sites in the future. Id. at 1148-49.

${ }^{145}$ Id. at 1150.

${ }^{146}$ See notes $117-19$ supra \& accompanying text.

${ }^{147}$ Notes 11-19 supra \& accompanying text. 
resented class-the future tenants in immediate need of housing. The court ensured that the project would be significantly delayed while AHA and HUD went through the cumbersome procedure of reevaluation. This in itself jeopardized the existence of the project, since construction costs rise rapidly and long delays could make it impossible for the project to be built within the cost limitations established by the original contract between AHA and HUD. Additionally, AHA might have decided that the project simply was not worth the effort required to relocate it, or might have refused to build any project at all in a white area. The end result therefore would have been no construction. The court did not appear to be as attuned to these possibilities as did the Croskey Street $\cdot$ court. ${ }^{148}$

Fortunately for the plaintiffs and for other indigent Austin residents, these expected results did not occur. The AHA has in fact built approximately 450 new public housing units in mixed or white, moderate- to lower-income neighborhoods of Austin. ${ }^{149}$ Although the AHA still owns the site originally planned for TEX 1-9, the project itself will not be built there..$^{150}$

Banks v. Perk ${ }^{151}$ is the most recent significant challenge to an LHA's site selection policies. It resulted in the issuance of a negative injunction. The class of all nonwhite tenants in and applicants for public housing in Cleveland brought suit against the Cuyahoga Metropolitan Housing Authority (CMHA) to enjoin, inter alia, planning and construction of any public housing in the racially impacted east side of Cleveland until public housing was distributed evenly throughout the city. ${ }^{152}$ The court

${ }^{148}$ Notes 133-36 supra \& accompanying text.

${ }^{149}$ The success of the plaintiffs in Blackshear conflicts with the gloomy predictions made in the model developed above. Two converging factors may explain this. On the one hand, Austin's political system may not be as well-organized as that in Chicago, where one mayoral regime has controlled the city for years and conflict and alliance have long been everyday elements of political life. Resistance to efforts to construct public housing could thus be less concerted or more fragilely structured in Austin than elsewhere. At the same time, the plaintiffs and their counsel probably can exert more political influence in a relatively small city such as Austin than in a huge urban center such as Chicago. To the extent that these observations are true, the model proposed in this Comment appears to have a somewhat strong orientation toward big cities with highly organized and well-structured political systems.

${ }^{150}$ Letter from William P. Allison, counsel for plaintiffs, to the University of Pennsylvania Law Review, Sept. 11, 1973.

151341 F. Supp. 1175 (N.D. Ohio 1972), modified on other grounds, No. 72-1576 (6th Cir., Jan. 8, 1973). The only case more recent than Banks is North Avondale Neighborhood Ass'n v. Cincinnati Metropolitan Housing Authority, 464 F.2d 486 (6th Cir. 1972), which is not discussed in this Comment because it involved an untimely complaint seeking to demolish a substantially completed project wherein no relief was granted.

152341 F. Supp. at 1177-78. A separate count of the complaint challenged the city's 
held that by contributing to residential segregation, despite the fact that it had acted "in good faith," 153 the CMHA had violated the fourteenth amendment. The remedy formulated by the court preliminarily enjoined CMHA from planning additional public housing in Cleveland's black neighborhoods. Furthermore, it appeared that the injunction would continue until some degree of balance in public housing locations was achieved..$^{154}$

The Banks court's remedy was a reasonable approach to this complex problem. Because CMHA had acted in good faith, there was reason to believe that it would sincerely attempt to place public housing in Cleveland's white neighborhoods. 155 The city of Cleveland had already signed a cooperation agreement with CMHA for the construction of 2,500 public housing units. ${ }^{156}$ Since Ohio law does not require government acquiescence in every site chosen for public housing, ${ }^{157}$ CMHA would be free to place the housing in white neighborhoods without fear of a veto by city council, if it wished to comply with the court's order. On the other hand, CMHA could have placed the units in white neighborhoods originally without judicial intervention if the institutional forces in Cleveland would have allowed it. In fact, the court recognized that the city administration had announced a policy of opposing public housing construction in any areas "where the majority of the residents were opposed to the projects," ${ }^{58}$ - the white areas of Cleveland. ${ }^{159}$ Thus opposition to CMHA efforts to integrate public housing would be expected. It appears, however, that without the court's order no public housing would be built in white areas; with it, 2,500 units might be. Nonetheless, the judicially fashioned answer alone will not overcome the institutional pressures which ultimately direct the actions of any housing authority.

power to revoke building permits that had been issued for construction of public housing. See notes 161-64 infra \& accompanying text.

153341 F. Supp. at 1182.

${ }^{154}$ Id. at 1184-86.

155 CMHA's good faith is attested to by its efforts to place public housing in Cleveland's suburbs. Mahaley v. Cuyahoga Metropolitan Housing Authority, 355 F. Supp. 1257, 1260-62 (N.D. Ohio 1973). However, given the fact that its "good faith" efforts of the past had led to segregated public housing sites, there was also good reason to believe that CMHA was susceptible to political persuasion by city agencies that did not want public housing located in white areas.

$156341 \mathrm{~F}$. Supp. at 1181 .

${ }^{157}$ See Ohio Rev. Code Ann. § 3735.52 (Page 1971).

158341 F. Supp. at 1178.

${ }^{159}$ The city is, of course, armed with a battery of delaying tactics. It has control over ministerial approval of roads, sewers, other public facilities, zoning and building permits. But see notes 160-73 infra \& accompanying text. 


\section{Housing Blocked by Ministerial Agencies}

Construction of public housing can also be stopped by the refusal of an agency, other than the LHA, to perform duties that are purely ministerial in nature. However, where there are clearly defined criteria for compliance, courts should be able to assist in the construction of public housing by ordering these agencies to perform their duties. In fact, this is probably the only situation in which courts can effectively aid in providing public housing to indigent families. ${ }^{160}$

Banks v. Perk ${ }^{161}$ involved, in fact, a correlative claim against a ministerial agency. Two public housing projects had been planned by the plaintiff, a private developer: Green Valley (132 units) and Crest Drive (18 units). The city, through the building inspector's office, revoked the permits in late 1971 and early 1972. The district court found that the revocations were "arbitrary, capricious and not in furtherance of any compelling governmental interest,"162 and held that equal protection, due process and the civil rights statutes had been violated. ${ }^{163}$ On appeal, the Sixth Circuit affirmed as to the smaller Crest Drive project, but reversed as to the Green Valley project, on the grounds that the holder of the building permit did not own the land on which the project was proposed. Since the issuance of the order to the ministerial agency, the expected result has indeed occurred. The city has not created any new obstacles to the issuance of the building permit or the construction of the project. The units are successfully under construction. ${ }^{\mathbf{1 6 4}}$

Another leading case in this area is Crow v. Brown. ${ }^{165}$ The relevant count of the complaint charged that after the county had rezoned two particular tracts of land for apartment construction, and plaintiffs ${ }^{166}$ purchased the land and made known their intention to build low-rent housing, ${ }^{167}$ the defendant

\footnotetext{
${ }^{180}$ See note 81 supra \& accompanying text.

161341 F. Supp. 1175 (N.D. Ohio 1972), modified, No. 72-1576 (6th Cir., Jan. 8, 1973).

${ }^{162^{*}} I d$. at 1179 .

${ }^{163} \mathrm{Id}$. at 1178-79. The statutes cited by the court were 42 U.S.C. $\S \S 1981,1983$, 2000d, 3601 (1970). See Kennedy Park Homes Ass'n v. City of Lackawanna, 436 F.2d 108 (2d Cir. 1970) cert. denied, 401 U.S. 1010 (1971), holding that the rezoning of a tract of land from an apartment zone to a park zone, solely to keep blacks and indigents out of the neighborhood, violated equal protection. The court ordered the zoning changed back to the original apartment classification. Id. at 114-15.

164 Letter from Lloyd B. Snyder, counsel for plaintiffs, to the University of Pennsylvania Law Review, Dec. 4, 1973.

165332 F. Supp. 382 (N.D. Ga. 1971), aff'd per curiam, 457 F.2d 788 (5th Cir. 1972). at 384 .

166 Plaintiffs in this count of the complaint were land developers. $332 \mathrm{~F}$. Supp.
}

167 The projects were not strictly public housing. Rather, they were "turnkey" 
county officials refused to issue building permits. Plaintiffs alleged that all standards for issuance of the permits had been met, and that the defendants' refusal was racially motivated. ${ }^{168}$ The court considered the evidence and found that "the only objection the County authorities have to [the projects] is that the apartments would be occupied by low-income, black tenants." 169 The refusal to issue a building permit was held to be a violation of equal protection. ${ }^{170}$

The remedy was simple. The court ordered the appropriate county official forthwith to issue building permits for the projects, and it enjoined all county officials from interfering with their completion. ${ }^{171}$ This remedy has proven effective. One project is nearly completed. The other would be completed but for sewage problems which caused some delays. Construction is now, however, proceeding normally. ${ }^{172}$ In a community in which strong neighborhood opposition to the projects had developed, ${ }^{173}$ such results indicate that courts truly can be effective when they need deal only with agencies whose duties are discrete, well-defined, and nondiscretionary.

\section{Conclusion}

There has never been any question that the powerless poor and black are unable to effect beneficial changes through the political and legislative process commonly reserved to the powerful and propertied. ${ }^{174}$ Though they may participate in sporadic legislative victories, the poor have never been able to view the nation's legislatures as long-term allies in the struggle against the inequities and biases of the private marketplace. It was thus with hope-mixed with a not unexpected strain of skepticism-that the poor turned to the courts during the early and middle 1960's to provide effective remedies against discrimination. This movement to the courts was reinforced by the Economic Opportunity Act of 1964 which enabled the Office

projects; the developer builds the housing, the LHA purchases it with federal funds, and the apartments are leased to low-income families. Id.

${ }^{168} \mathrm{Id}$.

${ }^{169}$ Id. at 389.

${ }^{170}$ Id. at $386-90$.

${ }^{171} I d$. at 395.

172 Interview with John R. Myer, counsel for plaintiffs, Oct. 3, 1973.

${ }^{173} \mathrm{Id}$.

${ }^{174}$ See K. Clark, Dark Ghetto 155 (1965):

Democratic government tends to be limited in its capacity to respond to the demands of minority or lower-status groups because it is necessarily dependent either upon majority support or upon those groups that already have economic, political, and social status and power. 
of Economic Opportunity to sponsor the Legal Services Program. ${ }^{175}$ The avowed purpose of the program was "to further the cause of justice among persons living in poverty by mobilizing the assistance of lawyers and legal institutions and by providing legal advice, legal representation, legal counseling; education in legal matters, and other appropriate legal services."176 In one six month period shortly after its creation, lawyers working in the Legal Services Program handled 92,000 cases, and won seventy-five percent of the 4,000 that went to trial. ${ }^{177}$ Federal officials commented that the program provided justice in the courts as an alternative to ghetto violence, and alleviated the general frustrations of indigence. ${ }^{178}$ By 1967, a Senate committee was willing to urge that more attention be given to test cases and law reform for the poor, in order "to help solve legal problems which confront the poor .... [and to make] the law more responsive to the needs of low-income persons." 179 The director of the Legal Services Program optimistically wrote in 1968 that the program "has already begun to make an historic impact on the poor of our country and the individuals, institutions and laws which affect them."180

However, on the evidence of this study of housing authority response to court orders, any hope placed by the poor in the Legal Services Program specifically, and in the judicial system generally, was misguided. ${ }^{181}$ Although the courtroom served the purpose of declaring that the indigent plaintiffs' rights had been violated by the LHA's, the judicial remedies have been hollow. Courts making such declarations have been woefully ill equipped to compel execution of their orders. Thus the tangible results of going to court have been minimal. The nominally neutral, equality-dispensing courts are not sufficiently armed to become embroiled in complex political conflict. With the ex-

175 Economic Opportunity Act of 1964, § 602(d), 42 U.S.C. § 2942(d) (1970).

${ }^{176}$ Economic Opportunity Amendments of 1967, § 222(a)(3), 42 U.S.C. § 2809(a)(3) (1970).

${ }^{177}$ N.Y. Times, Apr. 16, 1967, at 18, col. 8.

178 N.Y. Times, June 21,1967 , at 33, col. 3 .

${ }^{179}$ S. Rep. No. 563, 90th Cong., 1st Sess. 40 (1967). See also S. Rep. No. 453, 91st Cong., 1st Sess. (1969).

${ }_{180}$ Johnson, The O.E.O. Legal Services Program, 14 Catr. Law. 99, 110 (1968).

181 This is certainly not to imply that the program resulted in no benefits for the poor. See, e.g., King v. Smith, 392 U.S. 309 (1968).

The earliest origins of the Legal Services Program are explored in National Conference on Law \& Poverty, Conference Proceedings (1965); P. Wald, Law and Poverty (1965); Welfare Administration, U.S. Dep't of Health, Educ. \& Welfare, The Extension of Legal Services to the Poor (1964). Later analyses of the program's structure and functioning, and interpretations of the hopes it engendered, include: Carlin \& Howard, Legal Representation and Class Justice, 12 U.C.L.A.L. 
ception of actions against ministerial agencies whose functions are not discretionary, the shift in forum-from the state house to the courtroom- has not helped the poor. ${ }^{182}$ Because of the political system's incentive and reward structure, it is the rich and powerful, not the public housing tenants, who will succeed in any conflict. The functional specificity of the LHA's and their institutional alliances significantly reduce their susceptibility to external judicial influence. ${ }^{183}$

Compounding the inherent political recalcitrance, the courts have also failed to wield their contempt power in order to coerce intransigent LHA officials to perform their courtmandated duties. The reasons for judicial reluctance are not entirely clear. ${ }^{184}$ In order, therefore, to effectuate meaningful changes in the structural power of the LHA's and their institutional allies, the courts must more liberally use their only "political" lever.

One way to persuade the courts of the necessity of using contempt is to demonstrate that when it has not been used in site selection cases, the courts' orders have generally been ignored, and that the remedy of constitutional violations cannot otherwise be effectuated. ${ }^{185}$ The courts must begin to recognize, as has one commentator, that "employment of the contempt power is frequently the only, if not the most effective, instrument to insure that the orders of the court are fulfilled." 186 In the past, courts have, in fact, been persuaded that extremely strong use of contempt was necessary to force compliance with their orders; ${ }^{187}$ it has not yet happened, however, in a site selection case. For example, Judge Austin's failure to

Rev. 381 (1965); Gearan, General Comments on the Legal Services Program in New York City, 15 CATH. LAw. 356 (1969); Johnson, An Analysis of the OEO Legal Services Program, 38 Miss. L.J. 419 (1967); Note, Neighborhood Law Offices: The New Wave in Legal Services for the Poor, 80 HaRv. L. REv. 805 (1967); Mitgang, The Storefront Lauyer Helps the Poor, N.Y. Times, Nov. 10, 1968, § 6 (Magazine), at 34.

182 But see note 149 supra.

${ }^{183}$ Notes 68-77 supra \& accompanying text.

${ }^{184}$ See notes 61-64, 66 supra \& accompanying text.

${ }^{185} \mathrm{Cf}$. Swann v. Charlotte-Mecklenburg Bd. of Educ., 402 U.S. 1, 15 (1971) (dictum): "Once a right and a violation have been shown, the scope of a district court's equitable powers to remedy past wrongs is broad, for breadth and flexibility are inherent in equitable remedies."

${ }^{186}$ Cohen, The Contempt Power-The Lifeblood of the Judiciary, 2 Loyola U. CHI. L.J. 69 (1971).

${ }^{187}$ See Lance v. Plummer, 353 F.2d 585 (5th Cir. 1965), cert. denied, 384 U.S. 929 (1966) (Black \& Harlan, JJ., dissenting) (appellant violated injunction forbidding him from interfering with restaurants desiring to comply with Civil Rights Act; contempt order that he resign from his position as county's deputy sheriff until terms of injunction satisfied, court noting that this order would not interfere substantially with the county's operations); Meredith v. Fair, 313 F.2d 532 (5th Cir. 1962) (defendant gov- 
hold the Gautreaux defendants in contempt is an indication that, under present procedures, ${ }^{188}$ defendants will have to go very far indeed before they will be punished or coerced through contempt.

Although it would be ironic if the results of litigation in the last five years forced ghetto residents to return to the generally insensitive state houses and to Congress for redress, legislative reform may be the only answer. Statutorily stripping the insulation from the public authority structure of LHA's is the first step towards meaningful reform. ${ }^{189}$ If the local housing agency's commissioners were popularly elected by districts within the city, and if those officials had the resources to take a strong role in operating the agency, the influence of those indigents for whose benefit the public housing program exists might increase. ${ }^{190}$

At the risk of further bureaucratizing the housing agency, the funding scheme also ought to be modified. Giving control over the agency's budget to the state legislature might reduce the likelihood that the closely knit political alliance built around the housing agency will always prevail. ${ }^{191}$ Lastly, the legislature might allow for specific substantive remedies in order to relieve the courts from their judicially mandated conservatism. ${ }^{192}$

Whether or not ghetto residents dissatisfied with LHA site selection policies successfully return to the statehouse for remedies, it is clear that under present practice they will not, for

ernor violated order that plaintiff be allowed to enter the University of Mississippi; threatened with fine of $\$ 10,000$ per day and imprisonment until compliance).

${ }^{188} \mathrm{~A}$ possible means of spurring contempt proceedings might be to increase the specificity of the injunctive orders issued by trial judges. This would obviate the present problem of not knowing precisely when or if any one defendant had, in fact, violated an injunction. It would allow a trial judge to determine on a monthly or weekly basis whether the defendant was complying with his order. The problems with this solution, however, are two-fold. Orders that mandate a long series of specific steps in a legally and socially complex field are very difficult, in the technical sense, to write. Beyond that, judicial supervision of such orders would be extraordinarily time-consuming.

${ }^{189}$ Cf. note 22 supra.

${ }^{190}$ Additional influence, however, is not entirely determinative. Assuming that the city is divided over the issue of racial integration in housing, it is likely that the elected officials would reflect this political mixture and divide the LHA.

${ }^{191}$ See note 73 supra \& accompanying text. However, policy subsystems are just as likely to form here. Although the alliances are much more fluid on the state level, the poor are no more likely to be adequately represented.

${ }^{192}$ At the extreme, a court might be invested with the power to condemn private property sua sponte and order that the owner be paid just compensation by the federal government. Such property would then be used for public housing. Apparently, the courts have the power to order the expenditure of funds, including the levy of taxes to obtain them. Cf. Griffin v. County School Bd., 377 U.S. 218, 233 (1964) (dictum); Bradley v. Milliken, 484 F.2d 215, 258 (6th Cir.), cert. granted, 94 S. Ct. 538 (1973). 
the most part, achieve success by staying in the courtroom. Presently, a purely judicial response to a largely political problem will not succeed. Local housing interests are often powerful, well-entrenched and elusive. In respect to the chances for development of successful legal or political strategies for change in the highly complex area of public housing site selection, pessimism is entirely consistent with the available empirical evidence. 